\title{
Effectiveness of use of online games kahoot! chemical to improve student learning motivation
}

\author{
Leony Sanga Lamsari Purba ${ }^{1 *}$, Elferida Sormin ${ }^{2}$, Nelius Harefa ${ }^{1}$, Sumiyati ${ }^{1}$ \\ 'Department of Chemistry Education, Faculty of Teacher Training and Education, Universitas Kristen Indonesia, \\ Jakarta 13630, Indonesia \\ ${ }^{*}$ Corresponding author: leony.purba@uki.ac.id
}

\begin{abstract}
:
Qualitative descriptive study quasi-experimental method is intended to determine the effectiveness of using online games Kahoot! to increase student motivation to learn chemistry. The population in this study were all students of class X private secondary schools (SMAs) Pusaka 1 Jakarta. The sample was selected by random sampling technique, the entire class X MIA 1 with the number of 40 students. The results showed the use of online games Kahoot! effective to increase student motivation to learn chemistry. Increased motivation to learn by using the test gain with the gain of 0.73 with the interpretation of the increase motivation to learn the high category. All the indicators of motivation to learn, which has the intention to succeed in learning, to feel the need to be learned, have ideals, appreciate the lessons and study give a percentage increase motivation to learn different. The most significant increase occurred in the indicator have a desire to succeed in learning, with high gain values, namely 0.82 . The lowest increase occurred in the indicator value learning, the value of the gain medium, which is 0.70 . Thus, the use of online games Kahoot! help improve students' motivation to learn chemistry when applied to learning. Kahoot! use of online games! help improve students' motivation to learn chemistry when applied to learning. Kahoot! use of online games! help improve students' motivation to learn chemistry when applied to learning.
\end{abstract}

Keywords:

Chemical; industry 4.0; kahoot!; learning; media; motivation

\section{Introduction}

4.0 Industrial Revolution into a positive challenge for educators when this era. The technological advances in various fields is an important thing that must be considered. In a meeting of the World Economic Forum in Davos, Switzerland, Jack Ma revealed "Education is the biggest problem right now. If we do not change the path or system teaches it in 30 years later become a problem. We can not teach our children to compete with machines because they are smarter"(Melani, 2018). Teaching system in accordance with the demands of the industrial revolution 4.0 can be applied to the use of various media learning resources, teaching materials and technology-based learning media. Changes in teaching and contribute to the learning system and directly change the dynamics of education in accordance with the current challenges.

According to Law No. $12 \ln 2012$, education is a conscious and deliberate effort to create an atmosphere of learning and the learning process so that learners are actively developing the potential for him to have the spiritual power of religion, self-control, personality, intelligence, noble character, and skills needed him, society, nation, and country (Kemendikbud, 2012). High motivation to learn is one of the measures to improve the intelligence of children. Motivation to 
learn is internal and external encouragement to students who are learning to hold a behavior, in general, with some indicators or elements that support. These indicators, among others: the desire and work, encouragement and learning needs, hopes and aspirations of the future, the award in the study. Five conception of learning described by Säljö in Van-Rossum and Hamer (2010) are: (1) Learning as an increase in knowledge; (2) Learning as memorizing; (3) Learning as the acquisition of facts, procedures and so on, which can be maintained or used in practice; (4) Learning as an abstraction of meaning; and (5) Learning as an interpretive process that aims to understand the reality.

Motivation plays an important role in the learning process. Good motivation and learning go hand in hand. According to most psychologists motivation is essential for effective learning. Actually, the motivation is power to change or redirect the behavior; while studying modified from a variety of psychological factors (Shaheen, 2013). The relationship between motivation and learning issued by Suprijono (2009). He stated that the motivation to learn is a process that provides learning spirit, direction, and persistence of behavior. That is, the motivated behavior is that he is full of energy, focus, and long-lasting. Furthermore, Winkel (2003) defines that the study is the overall driving force in the students who led the activities and provide guidance on learning activities. Thus, the motivation born from the need to achieve the goal.

Motivation to learn is very important for the realization of learning achievement. To increase motivation to learn, states that we can identify some indicators in certain stages. Indicators of motivation are: (1) the duration of the activity; (2) the frequency of the activity; (3) persistence objective of the activity; (4) grit, tenacity and ability in the face of actions and difficulties to achieve the objectives; (5) devotion and sacrifice to achieve goals; (6) the degree of aspiration to be achieved by the activities carried out; (7) the level of attainment of qualifications; and (8) to its attitude toward the target activity. Hamzah (2008) defines the characteristics or indicators of motivation are: (1) the desire and the desire to succeed; (2) encouragement and learning needs; (3) expectations and ideals of the future; (4) the award in learning; (5) interesting activities; and (6) the existence of a conducive learning environment. Mean while, the dimensions and indicators of motivation based on the theory of motivation to learn Brophy and Good (1990) are: (1) the intrinsic dimension actively engaged in learning activities, encouragement to know things related to lessons and encouragement to learn independently; and (2) avoiding penalties teacher extrinsic dimension, the urge to get a compliment from a teacher, drive to please their parents, the desire to get good grades and encouragement of friends. encouragement to know things related to lessons and encouragement to learn independently. Based on several theories about the motivation to learn the above indicators, researchers studying motivation to develop indicators that will be used in this study. The indicator is (1) has no intention to succeed in learning; (2) feel the need to be studied, (3), aspires; (4) value learning; and (5) diligently studied.

According Susiwi (2007), chemistry learning should not rule out the discovery process chemistry concepts, for it takes the appropriate approaches and media during the learning process. All aspects of chemistry teaching should focus on learners change towards the better. One focus is student motivation. According Kasmadi and Indraspuri, subjects were classified as is chemistry lesson is tough enough for most high school students /MA. Advances in technology and science have drawn attention to the technological tools that appeal to the sense organs and require interaction with students in environmental education (Oskay et al. 2009). According to Hoffmann (2003), chemistry is the science of molecules and their transformation. It is a science that is not so much a hundred elements but of infinite molecular variations that can be built from the elements. One subject of high school chemistry class $X$ is a Chemistry bond. When the element forming compound, the element will take off, receive or share electrons so as to achieve stable 
electron configurations. Electronic theory of the bonding: the chemical bond is a special electron arrangement of atoms in which nuclei and electrons generated becomes more stable. The chemical bonds are grouped into two parts, namely the intermolecular bonding and bonding between the molecules. Intermolecular bonds consisting of ionic bonds (elektrovalen), covalent and coordinate covalent bonds. Intermolecular bonding consisting of hydrogen bonding, vanderwalls bonds, London forces and inter-dipole interactions Chang (2004).

Utilization of instructional media in accordance with the characteristics of learners, learning materials, curriculum, development of science and technology, will create a learning environment that is able to increase the motivation of learners. Online game-based learning media has been widely used to improve cognitive ability, psychomotor and affective student. According Purba (2019), research entitled an increased concentration of students through the use of evaluation in the course of learning quizizz Physical Chemistry 1 , showed an increase in the concentration of student learning through the use of learning evaluation quizizz in chemical physics course 1 was 0.45 , with the interpretation of the increase being.

Media other online game-based learning is Kahoot! Kahoot! is an online game which was developed to address the challenges in the learning process that makes students more concentration, more collaboration, comfortable in learning and increase motivation to learn by Nokham (2017). Almost all studies using instructional media Kahoot! berbasisis online game! as independent variables showed positive results against various dependent variable. Preliminary research indicates that integrates the GSR (ie., Kahoot!) Into the regular classroom lectures contributed to the increase in student involvement (Wang, 2015)

Assessment refers to the process of observing changes in the lives of people. In the assessment procedure, existing features are described in relation to the resources. Evaluation, on the other hand, is the decision-making process based on assessment results. The concept of combining the evaluation of ratings (Şaşmaz, 2014). Teachers should draw the attention of students during the learning, because their attention began to wane after the first ten minutes of learning. Teachers need to change the environment and engage students to regain their attention. Kahoot! online game! is a free assessment program that can be used anytime lessons to increase student participation for lessons by teachers and it can be used as a formative assessment, as well (Barnes, 2017). According Plump \& Larosa (2017), Kahoot! requiring instructor or the training of students is limited, is a means to provide vitality, student participation, and meta-cognitive support to class. This application was created and developed by teachers, students, business and social users (Susanti, 2017). Kahoot! can be easily accessed via smartphone or PC (Wichadee \& Pattanapichet, 2018).

Since March 2016, Kahoot! has been used by 20 million of the 55 million primary and secondary school students of America. Kahoot! online game! and similar applications is an important element in improving the cognitive capacity of students by offering different learning experiences ( $Y_{1} 1 \mathrm{maz}$, 2017). Underdal \& Sunde stated that Kahoot! plays an important role in gamification simple assessment program and contribute to the success of students at various levels (Bolat, 2017). Kahoot! tremendous impact on the dynamics of classrooms, student engagement, motivation, and learning seems to be a topic that is focused on learning topics that are relevant, and where there is little use of names that are too intrusive and behavior of students. In fact, consistent with the findings Papastergiou (2009), students noted that Kahoot! improvement of classroom dynamics, engagement, motivation and learning beyond what is expected of traditional teaching methods (eg, normal PowerPoint slides and chalk and speech). However, we were able to test the difference quantitative data collected; we hope to do so in future work. The themes identified support previous research that has found gsrs positive effect on, for example, the class dynamics (Rosas et 
al. 2003), learning, motivation, social interaction (Papastergiou, 2009; Wang, 2015), attention Kiili (2005) and a willingness to prepare for class (Wang, 2015). In terms of our contribution to this work, the study showed that the stiffness interpreted through the element of credibility because we provide a systematic procedure for encoding data and thematic extraction that can be attended by researchers in the future (Cope, 2014).

The results of further research with the title "Go Kahoot!' Enriching Classroom Engagement, Motivation and Learning with Games Experience shows that overall emuan revealed that the spreading Kahoot! enrich the quality of student learning in the classroom, with the highest reported influence on classroom dynamics, engagement, motivation and improved learning experience (Licorish et al. 2017; Licorish et al. 2018) Based on the results of the study entitled Implementation of the Digital Assessment Tool 'Kahoot!' in Elementary School that students feel, Kahoot! fun, informative, helpful, perfect, and nice. Students also assess the level of difficulty in using Kahoot! is the problem of internet connection, board reading difficulties, difficulties in selecting answers and termination of the application for connection time limit (ÇETIN, 2018). Research lrwan et al. (2019) entitled "Effectiveness of using kahoot! to improve learning outcomes ", indicating that Kahoot can be an alternative media interactive learning at the college since proven to significantly improve student learning outcomes. Based uaraian and various information above, researchers to test the effectiveness of using online games Kahoot! to increase student motivation to learn chemistry. Information obtained become one begi contribution of education in Indonesia.

\section{Methods}

This research is descriptive qualitative method of quasi independent variables are the online game Kahoot!, and the dependent variable is student motivation. The design of the study is: One group pretest-posttest group design.

The study was conducted in Jakarta SMAs Pusaka 1 October 2018. The population in this study were all students of class $X$ private secondary schools (SMAs) Pusaka 1 jakarta. The sample was selected by random sampling technique, the entire class X MIA 1 with the number of 40 students. Pemlihan sampling technique is done by selecting a number of randomized numbers. Data obtained from this study through questionnaires stuffing increase students' motivation has been validated by a validator expert. A total of five indicators of motivation to learn that is composed of 30 items with the statement following the Likert scale. Here grating each indicator motivation to learn that is used as an instrument in this study (Table 1)

Table 1

Grating indicator of motivation to learn

\begin{tabular}{cl}
\hline Number & Indicators Motivation \\
\hline 1 & Have the intention to succeed in learning \\
2 & Feel the need to be studied \\
3 & Aspires \\
4 & Rewarding Lessons \\
5 & Study diligently \\
\hline
\end{tabular}

In this research instruments used for data collection by giving questionnaires to the validator (expert, lecturer), then a questionnaire given to mahamahasiswa as a test subject. As presented in the description of this data is presented in the form of a frequency distribution per indicator along with the percentage of frequency and gain score. The procedure of this study is shown in 
Fig 1. Analysis of the data used in this study is to test the gain (increase motivation to learn), as shown in Table 2. Score calculation aims to find out how to increase student learning outcomes. Propose a formula to test scores as follows:

$$
G=\frac{\text { Posttest Score-Pretest Score }}{\text { Maxmimum Score-Pretest Score }}
$$

Table 2

Classification gain index

\begin{tabular}{ll}
\hline Value $\mathrm{g}$ & Interpretation \\
\hline 0.71 to 1.00 & High \\
0.31 to 0.70 & moderate \\
0 to 0.30 & Low \\
\hline
\end{tabular}

To obtain further information, in-depth interviews were conducted with reference to the gain test analysis results obtained from the processing of students' learning motivation questionnaire.

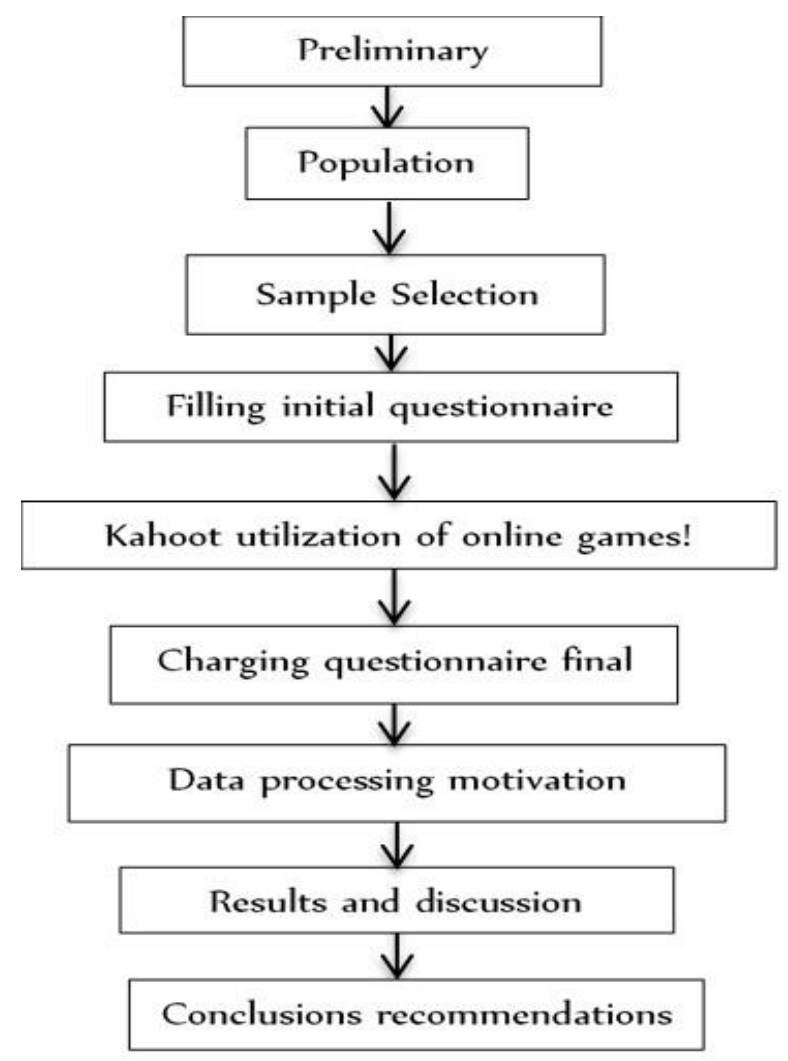

Fig 1. Research procedures

\section{Results and Discussion}

The instrument used in this study a learning motivation questionnaire composed of five indicators. Each indicator consists of six items following the statement and the entire item Likert scale. The entire statement item in the questionnaire, as many as 30 items declared valid by the validator 
experts with several related records EYD. Questionnaires filled out by the student experiment class and control class before and after the use of online games Kahoot!!

The data collection is done for the motivation to learn and then analyzed using the gain at the test each and the overall indicator. Here is the distribution of data filling a questionnaire on each indicator chemistry students' learning motivation (Table 3 ).

The results of questionnaire analysis the motivation to learn on the indicator has the intention to succeed in learning gained an average value gain of 0.82 of six statements presented. When interpreted into the gain, increased motivation to learn on this indicator, including the high category. The conclusion of six statements presented to obtain data on the motivation to learn on this indicator, item number 25 with the statement " 1 always want to get the highest score in class" is the highest gain value, namely 0.84 . Lowest gain value on this indicator amounted to 0.80 at item number 7 with the statement "l always thought must pass the KKM".

The results of questionnaire analysis the motivation to learn on the indicator will learn to feel the need gained an average gain value by 0.73 of six statements presented (Table 4). When interpreted into the gain, increased motivation to learn on this indicator, including the high category. The conclusion of six statements presented to obtain data on the motivation to learn on this indicator, item number 17 with the statement " 1 am asking chemistry that ditad 1 understand the teachers' and the item number 27 with the statement" 1 am asking chemistry that ditad 1 understand to a friend "is The highest gain value, namely 0.74 . Lowest gain value on this indicator was 0.70 in the item number 20 with the statement " 1 have spare time to go to the library to read a chemistry book".

\section{Table 3}

Indicators have the intention to succeed in learning

\begin{tabular}{ccccc}
\hline Item number & Early scores & Final score & Maximum score & Value Gain \\
\hline 1 & 75 & 144 & 160 & 0.81 \\
4 & 73 & 145 & 160 & 0.83 \\
7 & 72 & 142 & 160 & 0.80 \\
12 & 73 & 145 & 160 & 0.83 \\
24 & 70 & 143 & 160 & 0.81 \\
25 & 75 & 146 & 160 & 0.84 \\
\hline \multicolumn{5}{c}{ Average } \\
\hline
\end{tabular}

Table 4

Indicators feel the need to be Learning

\begin{tabular}{ccccc}
\hline Item number & Early scores & Final score & Maximum score & Value Gain \\
\hline 3 & 84 & 138 & 160 & 0.71 \\
10 & 85 & 140 & 160 & 0.73 \\
17 & 79 & 139 & 160 & 0.74 \\
20 & 72 & 134 & 160 & 0.70 \\
27 & 72 & 137 & 160 & 0.74 \\
28 & 81 & 139 & 160 & 0.73 \\
\hline \multicolumn{5}{c}{ Average } \\
\hline
\end{tabular}

The results of questionnaire analysis the motivation to learn on the indicator will learn to feel the need gained an average gain value by 0.71 of six statements presented (Table 5). When interpreted into the gain, increased motivation to learn on this indicator, including the high category. The conclusion of six statements presented to obtain data on the motivation to learn on 
this indicator, item number 21 with the statement "1 have to reach my goal" is the highest gain value, namely 0.74 . Lowest gain value on this indicator was 0.70 in the item number 9 with the statement "1 have to be successful in the field of chemistry"

The results of questionnaire analysis the motivation to learn on the indicator will learn to feel the need gained an average value gain of 0.70 of six statements presented (Table 6). When interpreted into the gain, increased motivation to learn on this indicator medium category. The entire item statement on this indicator gives equal value.

Table 5

Indicators aspires

\begin{tabular}{ccccc}
\hline Item number & Early scores & Final score & Maximum score & Value Gain \\
\hline 5 & 82 & 135 & 160 & 0.68 \\
9 & 78 & 135 & 160 & 0.70 \\
15 & 81 & 138 & 160 & 0.72 \\
18 & 85 & 140 & 160 & 0.73 \\
21 & 84 & 140 & 160 & 0.74 \\
22 & 85 & 138 & 160 & 0.71 \\
\hline \multicolumn{5}{c}{ Average } \\
\hline
\end{tabular}

Table 6

Rewarding Lessons

\begin{tabular}{lllll}
\hline ltem number & Early scores & Final score & Maximum score & Value Gain \\
\hline 2 & 80 & 134 & 160 & 0.68 \\
11 & 80 & 137 & 160 & 0.71 \\
14 & 87 & 139 & 160 & 0.71 \\
19 & 85 & 138 & 160 & 0.71 \\
23 & 85 & 139 & 160 & 0.72 \\
26 & 83 & 137 & 160 & 0.70 \\
\hline Average & & & 0.70 \\
\hline
\end{tabular}

The results of questionnaire analysis the motivation to learn on the indicator will learn to feel the need gained an average value gain of 0.72 of six statements presented (Table 7 ). When interpreted into the gain, increased motivation to learn on this indicator, including the high category. The conclusion of six statements presented to obtain data on the motivation to learn on this indicator, item number 16 with the statement "1 am happy to repeat the lesson at home" and item number 29 with the statement " 1 always do my homework" is the highest gain value, namely 0.75 . Lowest gain value on this indicator amounted to 0.69 at item number 6 with the statement "I followed private tutoring chemistry".

\section{Table 7}

Indicators Diligent Learning

\begin{tabular}{lllll}
\hline ltem number & Early scores & Final score & Maximum score & Value Gain \\
\hline 6 & 73 & 133 & 160 & 0.69 \\
8 & 75 & 135 & 160 & 0.71 \\
13 & 75 & 136 & 160 & 0.72 \\
16 & 76 & 139 & 160 & 0.75 \\
29 & 76 & 139 & 160 & 0.75 \\
30 & 76 & 137 & 160 & 0.73 \\
\hline Average & & & 0.72 \\
\hline
\end{tabular}


In general, students' motivation to learn chemistry after use Kahoot online games! significantly increased. This is reflected in the gain test results that show the value of 0.73 with the interpretation of the increase motivation to learn the high category. The most significant increase occurred in the indicator have a desire to succeed in learning, with high gain values, namely 0.82 . The lowest increase occurred in the indicator value learning, the value of the gain medium, which is 0.70 . Based on the analysis of each indicator statement item's bullet, the following is a diagram of an increase in motivation to learn chemistry students after the use of online games Kahoot! (Fig 2).

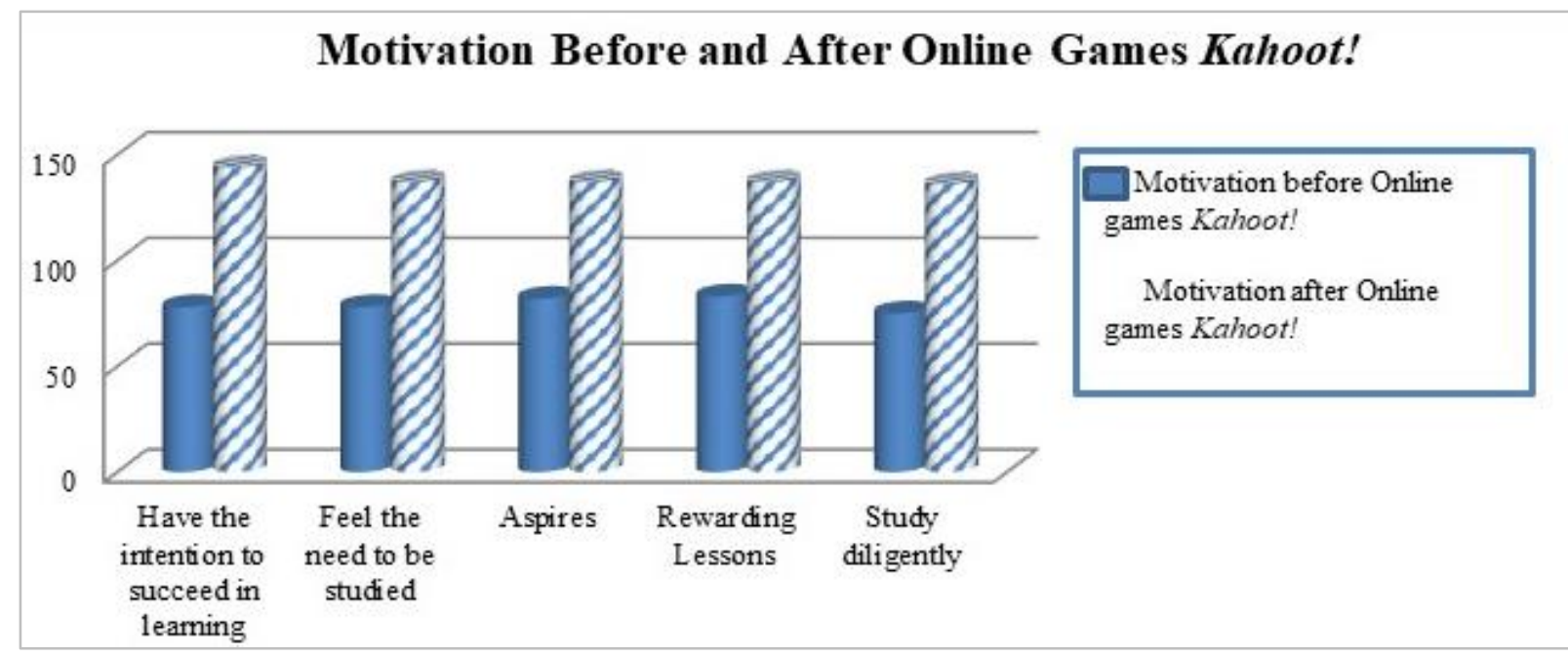

Fig 2. Motivation before and after online games Kahoot!

Based on the analysis above, when examined theoretically Kahoot! tremendous impact on the dynamics of classrooms, student engagement, motivation, and learning. It became the cause of the basis of his high motivation to learn chemistry student improvement after using this application. Conventional learning and evaluation that is familiar to the students, so the concept of the student's mind about cheating is embedded. Have the intention to succeed in learning to contribute most to the improvement of learning motivation is supported by direct feedback received by students after submit answers to each question presented in kahoot!. While indicators appreciate contributed most low because students are busy with themselves and the tools they use in online games Kahoot!

Results of interviews with students were used as a sample in the study, the researchers concluded the use of online games Kahoot! fun and mengaharuskan students to understand the concepts of the lessons, so have much to learn before using it.

\section{Conclusion}

Based on these results, the researchers concluded Kahoot use of online games! increase motivation to learn chemistry students with high category, with a gain of 0.73 . The most significant increase occurred in the indicator have a desire to succeed in learning, with high gain values, namely 0.82 . The increase in the low, the indicator value learning, the value of the gain medium, which is 0.70 . Game online Kahoot! both used for evaluation of learning chemistry. To broaden understanding of the use of online games Kahoot !, necessary to do research on subjects in addition to chemical and or on a different character than the motivation to learn. 


\section{Acknowledgments}

The author of the contribution would like to thank the research team, the principal and viceprincipal and the chemistry teacher at SMAs Pusaka 1 jakarta. Acknowledgments also thank the authors of the Christian University of Indonesia for helping us fund the research that we have carried out.

\section{References}

Barnes, R. (2017). Kahoot! in the classroom: Student engagement technique. Nurse Educator, 42(6), 280, doi: 10.1097/NNE.0000000000000419

Bolat, Y. i., Şimşek, Ö., \& Ülker, Ü. (2017). Oyunlaştırılmış çevrimiçi sınıf yanıtlama sisteminin akademik başarıya etkisi ve sisteme yönelik görüşler. Abant lizzet Baysal Üniversitesi Eğitim Fakültesi Dergisi, 17(4), 1741-1761, doi: 10.17240/aibuefd.2017.17.32772-363964

Brophy, J. L. and Good, T. E. (1990). Educational psychology: A realistic approach. 4th edn: White Plains, NY: Longman.

Çetin, H. S. (2018). Implementation of the digital assessment tool 'Kahoot!' in elementary school. International Technology and Education Journal, 2, 9-20.

Chang, R., Weissman, K. (2004). Kimia dasar konsep-konsep inti. Edisi ke-3. Penerbit Erlangga; Jakarta

Cope, D. (2014). Methods and meanings: credibility and trustworthiness of qualitative research. Oncology Nursing Forum, 41(1), 89-91, doi: 10.1188/14.onf.89-91

Van-Rossum, E. J., \& Hamer, R. (2010). The meaning of learning and knowing. Rotterdam: Sense Publishers.

Irwan, 1., Luthfi, Z. F., \& Waldi, A. (2019). Efektifitas Penggunaan Kahoot! untuk meningkatkan hasil belajar siswa [Effectiveness of using Kahoot! to improve student learning outcomes]. PEDAGOGIA: Jurnal Pendidikan, 8(1), 95, doi: 10.21070/pedagogia.v8i1.1866

Hamzah, U. B. (2008). New orentation on learning psychology. Jakarta: Bumi Aksara.

Hamzah. B. Uno. (2013). Teori motivasi dan pengukurannya. Jakarta: Bumi Aksara

Hoffmann, D. (2003). Medical herbalism: The science and practice of herbal medicine, Rochester: Inner Traditions/Bear and Company. 101-103.

Kemendikbud. (2012). Undang-Undang RI No 12 Tahun 2012 Tentang Pendidikan Tinggi. (Online), http://sipuu.setkab.go.id/PUUdoc/17624/UU0122012_Full.pdf. Diakses 23 Mei 2018 pukul 18.30

Kiili, K. (2005). Digital game-based learning: Towards an experiential gaming model. Internet and Higher Education, 8(1), 13-24, doi: 10.1016/j.iheduc.2004.12.001

Licorish, S. A., George, J. L., Owen, H. E., \& Daniel, B. (2017). Go Kahoot!” enriching classroom engagement, motivation and learning experience with games. In Proceedings of the 25th International Conference on Computers in Education (pp. 755-764).

Licorish, S. A., Owen, H. E., Daniel, B., \& George, J. L. (2018). Students' perception of Kahoot!'s influence on teaching and learning. Research and Practice in Technology Enhanced Learning, 13(1), 9, doi: 10.1186/s41039-018-0078-8

Melani, Agustina, “Jack Ma: Ubah Pendidikan agar Bersaing dengan Robot," Liputan 6, 25 Jan 2018, 13:04 WIB. (Online), https://www.liputan6.com/bisnis/read/3238241/jack-ma-ubah-pendidikanagar-bersaing-dengan-robot.

Nokham, Y. C. R. (2017). The effect of Kahoot, Quizizz and Google Forms on thestudent's perception in classrooms response system,. Econ. Sustain. Growth, ICDAMT , 178-182

Oskay, O., Erdem, E., Akkoyunlu, B., and Yilmaz, A., (2009). Prospective Chemistry Teachers' Learning Styles And Learning Preferences, Innovation and Creativity in Education 2:1362-1367 
Papastergiou, M. (2009). Digital game-based learning in high school computer science education: Impact on educational effectiveness and student motivation. Computers \& Education, 52(1), 112. doi: 10.1016/j.compedu.2008.06.004

Plump, C. M., \& LaRosa, J. (2017). Using Kahoot! in the classroom to create engagement and active learning: A game-based technology solution for elearning novices. Management Teaching Review, 2(2), 151-158, doi: 10.1177/2379298116689783

Purba, L. S. L. (2019). Peningkatan konsentrasi belajar mahasiswa melalui pemanfaatan evaluasi pembelajaran quizizz pada mata kuliah kimia fisika l. Jurnal Dinamika Pendidikan, 12(1), 29-39.

Rosas, R., Nussbaum, M., Cumsille, P., Marianov, V., Correa, M., Flores, P., et al. (2003). Beyond nintendo: Design and assessment of educational video games for first and second grade students. Computers and Education, 40(1), 71-94, doi: 10.1016/s0360-1315(02)00099-4

Shaheen, S., Nighat Perveen, N., \& Malikz, S. K. (2013). Motivational techniques for effective learning: a meta analysis motivational techniques for effective learning: A meta analysis. Elixir International Journal, 19170-19176.

Suprijono, A. (2009). Cooperative learning teori dan aplikasi PAIKEM. Yogyakarta: Pustaka Pelajar. Susanti, S. (2017). Fun Activities in English by Using Kahoot!!! 2nd International Seminar on Education 2017 Empowering Local Wisdom on Education for Global lssue.

Susiwi, S. (2007). Pendekatan Pembelajaran dan Pembelajaran Kimia. Bandung: Jurusan Pendidikan Kimia FMIPA UPI

Sasmaz, O. F. (2014). Fen bilimlerinde alternatif ölçme değerlendirme. S. S. Anagun ve N. Duban (Ed.), Fen bilimleri ögretimi (pp.277-340). Ankara: Anı Yayıncılık.

Wang, A. l. (2015). The wear out effect of a game-based student response system. Computers $\mathcal{E}$ Education, 82, 217-227, doi: 10.1016/j.compedu.2014.11.004

Wichadee, S., \& Pattanapichet, F. (2018). Enhancement of performance and motivation through application of digital games in an English language class. Teaching English with Technology, 18(1), 77-92.

Winkel, W. S. (2003). Educational psychology and learning evauation. Jakarta: Gramedia 